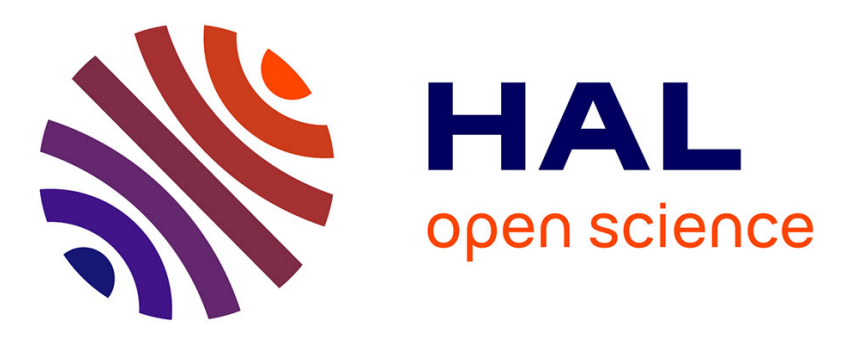

\title{
Using a toroid transducer for thermal ablation by high-intensity-focused ultrasound increases the coagulated volume.
}

David Melodelima, William Apoutou N'Djin, Hubert Parmentier, Michel

Rivoire, Jean-Yves Chapelon

\section{To cite this version:}

David Melodelima, William Apoutou N'Djin, Hubert Parmentier, Michel Rivoire, Jean-Yves Chapelon. Using a toroid transducer for thermal ablation by high-intensity-focused ultrasound increases the coagulated volume.. Journal of the Acoustical Society of America, 2008, 123 (5), pp.2995. 10.1121/1.2932545 . inserm-00294599

\section{HAL Id: inserm-00294599 https://www.hal.inserm.fr/inserm-00294599}

Submitted on 9 Jul 2008

HAL is a multi-disciplinary open access archive for the deposit and dissemination of scientific research documents, whether they are published or not. The documents may come from teaching and research institutions in France or abroad, or from public or private research centers.
L'archive ouverte pluridisciplinaire HAL, est destinée au dépôt et à la diffusion de documents scientifiques de niveau recherche, publiés ou non, émanant des établissements d'enseignement et de recherche français ou étrangers, des laboratoires publics ou privés. 
Using a toroid transducer for thermal ablation by high-intensity-focused ultrasound increases the coagulated volume

\section{David Melodelima $\mathrm{PhD}^{1}$, William A. N'Djin ${ }^{1}$, Hubert Parmentier $\mathrm{MD}^{1}$, Michel Rivoire MD, $\mathrm{PhD}^{1,2}$ and Jean-Yves Chapelon $\mathrm{PhD}^{1}$}

Here, we report that a new design of High Intensity Focused Ultrasound transducer can significantly enlarge the coagulated volume over short periods of time, and that treatment in the liver can be guided in real-time using an integrated ultrasound imaging probe. Eight ultrasound emitters, divided into 256 elements, were created by sectioning a single toroid piezocomposite transducer. The focal zone was conical in shape and located $70 \mathrm{~mm}$ from the transducer; enabling the treatment of deep-seated tumors. A single thermal lesion was created when the eight emitters performed alternative and consecutive $5 \mathrm{~s}$ ultrasound exposures. This paper presents in vivo evidence that the coagulated volume obtained from a $40 \mathrm{~s}$ total exposure in the liver was $7.0 \pm 2.5 \mathrm{~cm}^{3}\left(\min 1.5-\max 20.0 \mathrm{~cm}^{3}\right)$. All lesions were visible with high contrast on sonograms. The correlation between the diameter of lesions observed on sonograms and during gross examination was $92 \%$. This method also allowed the user to easily enlarge the coagulated volume by juxtaposing single lesions. This approach may have a role in treating unresectable colorectal liver metastases and may also be used in conjunction with resection to extend its limits. 